RASĀYAN J. Chem.

Vol. 13 | No. 4 |2577-2581| October - December | 2020 ISSN: 0974-1496 | e-ISSN: 0976-0083 | CODEN: RJCABP

\title{
FLAVONOIDS CONSTITUENT ANALYSIS AND CELL CYCLE INHIBITION ACTIVITY OF ETHYLACETATE EXTRACT OF Vernonia amygdalina Delile. LEAVES ON LUNG CANCER CELL LINE
}

\author{
P.A.Z. Hasibuan ${ }^{1, *}$, D. Munir ${ }^{2}$, D. Pertiwi ${ }^{3}$, D. Satria ${ }^{3}$ and M.F. Lubis ${ }^{1}$ \\ ${ }^{1}$ Departement of Pharmacology, Faculty of Pharmacy, Universitas Sumatera Utara, Medan, \\ 20155, Indonesia \\ ${ }^{2}$ Departement of Otolaryngology Head and Neck Surgery, Faculty of Medicine, Universitas \\ Sumatera Utara, Medan, 20155, Indonesia \\ ${ }^{3}$ Departement of Pharmaceutical Biology, Faculty of Pharmacy, Universitas Sumatera Utara, \\ Medan, 20155, Indonesia \\ *E-mail: poppyanjelisa@usu.ac.id
}

\begin{abstract}
Lung cancer is one type of cancer with the high incidence rate in the world, and it is very important to find the best treatment therapy to reduce the problem of lung cancer. African leaves (Vernonia amygdalina Delile.) have long been used as medicine in the world of health. This study evaluated the anticancer activity of ethylacetate extract (EAE) of Vernonia amygdalina Delile. leaves towards HTB-182 cell line. EAE was analyzed for flavonoids constituent and tested for cytotoxicity, cell cycle inhibition, apoptosis induction and inhibition of PI3KCA, EGFR and VEGFR-2 genes expression. EAE was found to contain quercetin, quercetin 3-O- $\alpha$-L-arabinopyranoside and isoquercetin. EAE of Vernonia amygdalina Delile. leaves were found to have $\mathrm{IC}_{50}$ of $10.37 \pm 0.16 \mu \mathrm{g} / \mathrm{mL}$, caused accumulation in $\mathrm{S}$ and $\mathrm{G}_{2}$-M phase, caused apoptosis and decreased PI3KCA, EGFR and VEGFR-2 genes expression. The results reveal that EAE of Vernonia amygdalina Delile. leaves have cytotoxic activities by inhibition of cell cycle. Our further study is to isolate compounds responsible for the cytotoxic activity.

Keywords: Cell Cycle, Chemical Constituents, Vernonia amygdalina Delile., Leaves, Ethylacetate Extract.
\end{abstract}

(C) RASĀYAN. All rights reserved

\section{INTRODUCTION}

Lung cancer is one of the leading types of cancer that causes cancer deaths in the world, even if the mortality rates of several types of cancer are combined. ${ }^{1}$ In 2018 lung cancer became the type of cancer with the most number of new cases, namely 2.1 million new cases with a percentage of $11.6 \%$ of all types of cancer cases that occurred. Lung cancer is responsible for around 1.8 million cases of death or about $18.4 \%$ of the total cancer deaths in the world. ${ }^{2}$ The high death due to lung cancer cases is inseparable from early diagnosis of poor cancer, genetic changes in cancer cells and limited treatment therapy, such as surgery, chemotherapy and radiotherapy. 3,4

Vernonia amygdalina Delile. from a family of Asteraceae come from West Africa. Phytochemical constituents such as steroidal saponins, sesquiterpene lactones, flavonoids, fatty acids have indicated some pharmacological activity such as anti-malaria, anti-inflammation, anti-tumor, anti-obesity, and other activities. ${ }^{5-15}$ The purpose of this study was to evaluate of flavonoids constituent and cell cycle inhibition activity of ethylacetate extract of Vernonia amygdalina Del. Leaves towards HTB-182 lung cancer cells.

\section{EXPERIMENTAL}

\section{Preparation of Fractions}

The air-dried and powdered leaves of Vernonia amygdalina Delile. $(500 \mathrm{~g})$ were repeatedly fractionated by maceration method based on previous studies. ${ }^{16-19}$ 
RASĀYAN J. Chem.

Vol. 13 | No. 4 |2577-2581| October - December | 2020

Flavonoids Constituent Analysis with LC-MS/MS

Analysis of flavonoids from EAE was analyzed with TSQ Quantum ${ }^{\mathrm{TM}}$ Access Max Triple Quadrupole Mass Spectrometer with mobile phase A $(0.1 \%$ formic acid in water and B $(0.1 \%$ formic acid in acetonitrile $)$ with gradient method and flow rate $250 \mu \mathrm{L} /$ minute, for the column using Hypersil GOLD aQ $50 \times 2.1 \mathrm{~mm}$ x 1.9 $\mu \mathrm{m}$ and the time for analysis was 7.5 minute. The results were analyzed with $\mathrm{x}$-Calibur software. ${ }^{20}$

\section{Cytotoxicity Activity}

HTB-182 cell line $\left(1 \times 10^{4}\right.$ cells $)$ were grown in DMEM complete medium. After 24 hours of incubation, the medium was discharged and treated by EAE. The further procedure was followed as previously describe. ${ }^{18,21,22}$

\section{Cell Cycle Inhibition Analysis}

HTB-182 cell line (1x106 cells) were seeded into 6-well plate and incubated for 24 hours in incubator $\mathrm{CO}_{2}$ $5 \%$. for the treatment, harvested and analysis of cells with flow cytometer were followed procedure from previous study. ${ }^{19,23}$

\section{Observation of Apoptosis}

HTB-182 cell line ( 1 x $10^{5}$ cells/well) were seeded into 24-well plate on coverslips and incubated for 24 hours. After that, the cells were treated and incubated for 24 hours. The $10 \mu \mathrm{L}$ acridine orange-ethidium bromide was added and incubated for 15 minutes and inspected under the confocal microscope. ${ }^{24}$

\section{Expression of PI3KCA, EGFR and VEGFR-2}

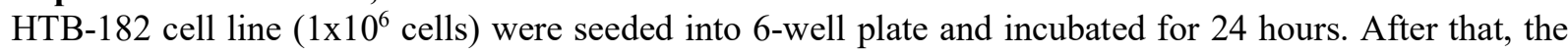
cells were treated with EAE $2.5 \mu \mathrm{g} / \mathrm{mL}$ and then incubated for 24 hours. Isolation RNA and cDNA synthesis procedures were adopted from the reported literature. ${ }^{25-26}$ The gene expression of PI3KCA, EGFR and VEGFR-2 were determined by RT-PCR. The oligonucleotide primers for PI3KCA, Akt-1, Akt-2 and betaactin were shown on Table-1.

Table-1: Primers Sequences, Size Product and Annealing Temperature

\begin{tabular}{c|c|l|c|c}
\hline Gene & & \multicolumn{1}{|c|}{ Primer Sequences } & Size (bp) & $\begin{array}{c}\text { Temp } \\
\left({ }^{\circ} \mathrm{C}\right)\end{array}$ \\
\hline \multirow{2}{*}{ VEGFR-2 } & $\mathrm{F}$ & $\begin{array}{l}\text { 5'-GTGTCAGAATCCCTGCGAAGTA -3' } \\
\text { 5'-GAAATGGGATTGGTAAGGATG -3' }\end{array}$ & 280 & 55.5 \\
\hline \multirow{2}{*}{ EGFR } & $\mathrm{F}$ & $\begin{array}{l}\text { 5'-CAACATCTCCGAAAGCCA-3' } \\
\text { 5'-CGGAACTTTGGGCGACTAT-3' }\end{array}$ & 660 & 58 \\
\hline \multirow{2}{*}{ PI3KCA } & $\mathrm{F}$ & $\begin{array}{l}\text { 5'-GGACAATCGCCAATTCAG-3' } \\
\text { 5'-TGGTGGTGCTTTGATCTG-3' }\end{array}$ & \multirow{2}{*}{300} & \multirow{2}{*}{53.5} \\
\hline \multirow{2}{*}{$\beta$-actin } & $\mathrm{F}$ & $\begin{array}{l}\text { 5'-GCTCCTCCTGAGCGCAAGT-3' } \\
\text { (',-TCGTCATACTCCTGCTTGCTGAT-3' }\end{array}$ & 105 & \multirow{2}{*}{58} \\
\hline
\end{tabular}

\section{Flavonoids Constituent of EAE}

\section{RESULTS AND DISCUSSION}

Flavonoids constituent analysis from EAE was determined to obtain the information of flavonoids contain in EAE with LC-MS/MS. The result was given in Fig.-1 and Table-2.

Table-2: Flavonoids Constituent of EAE

\begin{tabular}{c|l|c|c}
\hline No. & \multicolumn{1}{|c|}{ Compound } & Molecule Structure & Molecule Weight \\
\hline 1 & Quercetin & $\mathrm{C}_{15} \mathrm{H}_{10} \mathrm{O}_{7}$ & 302.2360 \\
\hline 2 & Quercetin 3-O- $\alpha$-L-arabinopyranoside & $\mathrm{C}_{20} \mathrm{H}_{18} \mathrm{O}_{11}$ & 434.3530 \\
\hline 3 & Isoquercetin & $\mathrm{C}_{21} \mathrm{H}_{20} \mathrm{O}_{12}$ & 464.0955 \\
\hline
\end{tabular}

The results were showed that EAE contains some flavonoids such as quercetin, quercetin $3-O-\alpha-\mathrm{L}-$ arabinopyranoside and isoquercetin. The profile was predicted based on molecule weight and fragmentation pattern. Predictions were analyzed based on a percentage of similarity between the target compound and library on the computer used software. ${ }^{20}$ 
RASĀYAN J. Chem.

Vol. 13 | No. 4 |2577-2581| October - December | 2020

E:IDATA RAWI...IF_Usu_Afirtaa_3

RT: $0.00-7.50$ SM: $3 B$

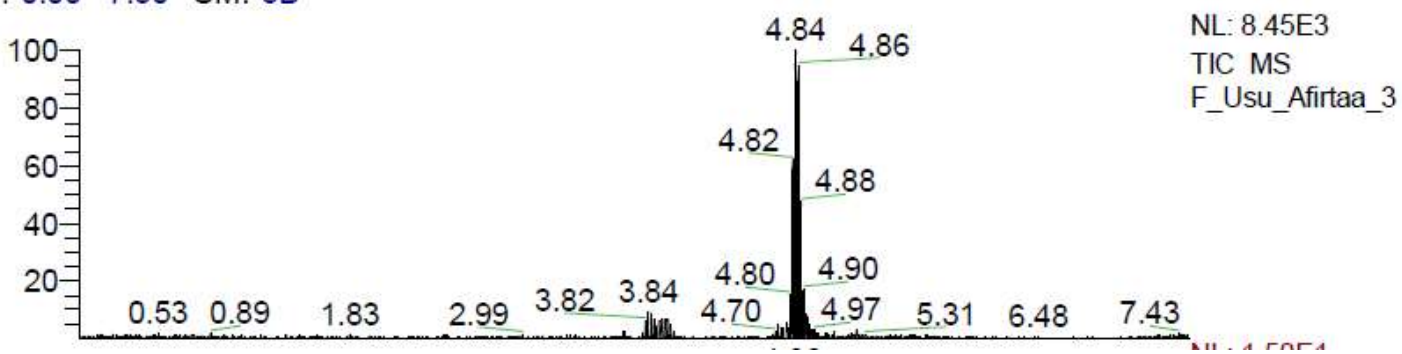

Fig.-1: Chemicals Constituent of EAE with LC-MS/MS

Inhibitory Concentration $50 \%\left(\mathrm{IC}_{50}\right)$

The $\mathrm{IC}_{50}$ value of EAE on HTB- 182 cells was $10.37 \pm 0.16 \mu \mathrm{g} / \mathrm{mL}$. The cytotoxicity estimate of a natural product is related to the content of active compounds in these plants including Vernonia amygdalina Delile. Flavonoids are estimated as active compounds. ${ }^{27}$ This fact was to indicate that EAF can inhibit cell growth that $\mathrm{S}$ and $\mathrm{G}_{2} / \mathrm{M}$ phase on cell cycle. The isolated polyphenols from plants including kaemferol, quercetin, anthocyanins, coumarin acid, and ellagic acid were shown to inhibit the growth (inhibit cell cycle and induce apoptosis) of human breast (MCF-7), oral (KB, Cal-27), colon (HT-29, HCT-116), and prostate (LNCaP, DU-145) tumor cell lines. ${ }^{28-31}$

\section{Analysis of Cell Cycle}

The effect of EAE is given in Fig. -2 . Whereas treatment of EAE $2.5 \mu \mathrm{g} / \mathrm{mL}$ caused cell accumulation at $\mathrm{S}$ and $\mathrm{G}_{2} / \mathrm{M}$ phase (16.19\% and $\left.19.74 \%\right)$ and for the control cell $(13.9 \%$ and $14.78 \%)$.

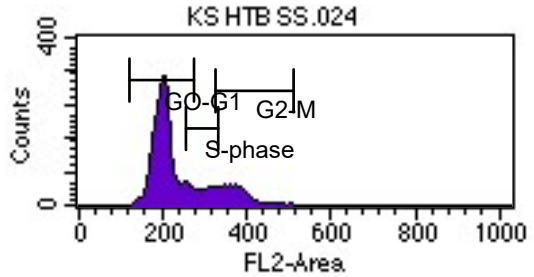

a

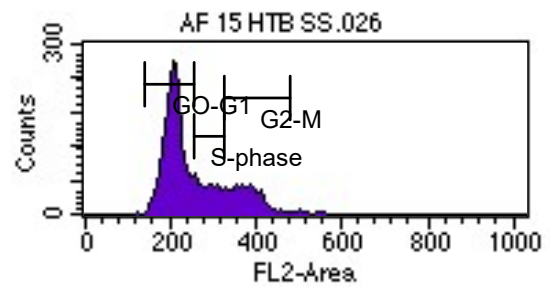

\section{Apoptosis}

Fig.-2: Percentage of Cell Cycle Phase of HTB-182 Cells. (a) Control Cell, (b) EAE $2.5 \mu \mathrm{g} / \mathrm{mL}$

Apoptosis can be defined as a process of programmed cell death and this process depends on the biochemical mechanism of the cell. In this study ${ }^{24}$, Figure- 3 showed EAE was induced apoptosis. Apoptosis HTB-182 cells were observed used a confocal microscope. HTB-182 cells were treated with EAE with a concentration $2.5 \mathrm{ug} / \mathrm{mL}$.

\section{PI3KCA, EGFR and VEGFR-2 Genes Expression}

RT-PCR method was used to evaluated PI3KCA, EGFR and VEGFR-2 gene expression in HTB-182 cells after the treatment with EAE $2.5 \mu \mathrm{g} / \mathrm{mL}$. EAE showed a significant down-regulatory effect on the expression of PI3KCA (0.54 \pm 0.02$)$; EGFR $(0.62 \pm 0.01)$, and VEGFR-2 $(0.74 \pm 0.02)$ after treatment of EAE at $2.5 \mu \mathrm{g} / \mathrm{mL}$. The inhibition of EAE towards PI3KCA, EGFR and VEGFR-2 genes expression in HTB-182 are given in Fig.-4.

$\mathrm{PI} 3 \mathrm{KCA}$ is one of kinase protein which regulates the development of cancer through $\mathrm{PI} 3 \mathrm{~K} / \mathrm{Akt} / \mathrm{mTOR}$ pathway and quercetin can reduce the expression of serin/threonine kinase, Akt, mTOR, MAPK, ERK1/2, JNK proteins. ${ }^{32}$ EGFR and VEGFR-2 are a transmembrane receptor that plays an important role in endothelial cell development and is thought to mediate the key effect of the endothelial-specific mitogen VEGF on cell proliferation and permeability. ${ }^{33}$ Therefore, the majority of VEGFR-2 actions are related to angiogenesis. VEGFR-2 receptors and VEGFR-2 mRNA are largely expressed in breast cancer. ${ }^{34}$ 
RASĀYAN J. Chem. Vol. 13 | No. 4 |2577-2581| October - December | 2020

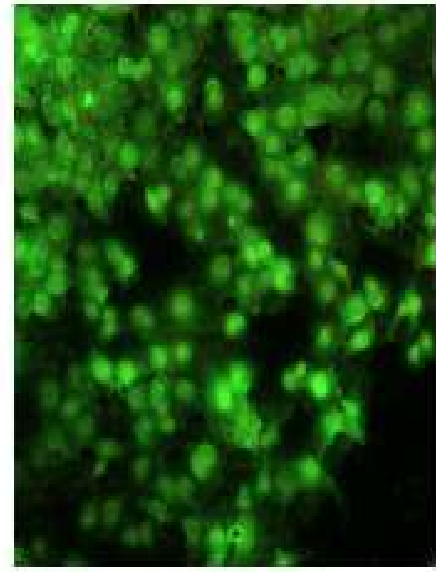

(a)

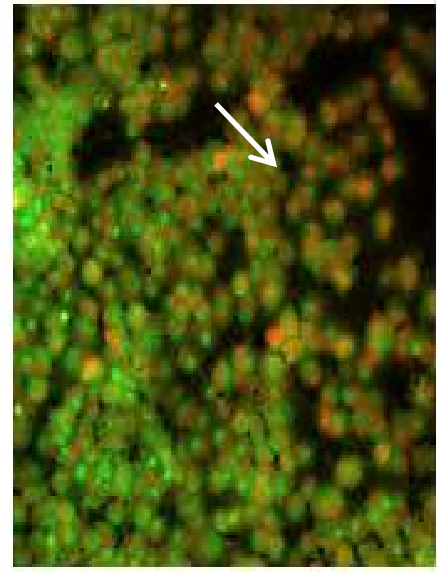

(b)

Fig.-3: Apoptosis Analysis. HTB-182 Cells. (a) Control Cells; (b) EAE $2.5 \mu \mathrm{g} / \mathrm{mL}(\searrow$ apoptosis Cells).

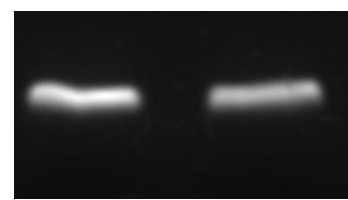

a

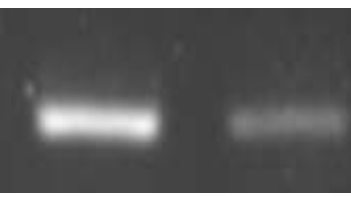

b

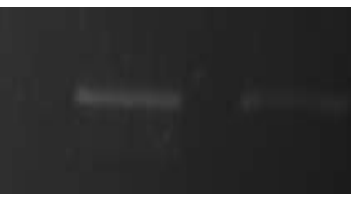

$\mathrm{c}$

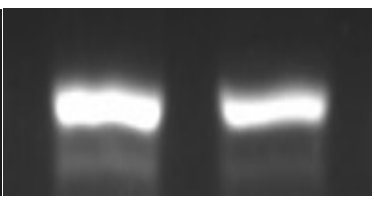

d

Fig.-4: Gene Epression after Treatment with EAE. (a) $\beta$-actin Expression; (b) PI3KCA Expression; (c) EGFR

Expression; (d) VEGFR-2 Expression

\section{CONCLUSION}

The results reveal that ethylacetate extract of Vernonia amygdalina Delile. leaves contain quercetine and its derivates compounds and effective as anticancer towards HTB-182 cell lines by several mechanisms such as cell cycle inhibition, apoptosis induction and decrease PI3KCA, EGFR and VEGFR-2 genes expression.

\section{ACKNOWLEDGEMENT}

This research was funding by Universitas Sumatera Utara through Non PNBP USU funding 2019 research grant No. 4167/UN.5.1.R/PPM/2019 (01 April 2019).

\section{REFERENCES}

1. C.P. Andika, N. Fariz, A. Sita, Z. Jamal, S. Elisna, $C D K-2324,42$, 833(2015).

2. World Health Organization, International Agency for Research on Cancer, pp. 1-3 (2018), DOI:10.1002/ijc.31937

3. C. Wei, W. Jun, L. Sulai, W. Shaoqiang, C. Yuanda, Z. Wolong, Journal of Experimental and Clinical Cancer Resaearch, 35, 1(2016), DOI:10.1186/s13046-016-0357-4

4. H. Jayoung, J. Paiboon, A. Olufunmilola, K. Dongwo, International Journal of Enviromental Research and Public Health, 15, 1(2018), DOI:10.3390/ijerph15071509

5. H. Ohigashi, M. Jisaka, T. Takagaki, H. Nozaki, Agricultural and Biological Chemistry, 55, 1201(1991), DOI:10.1080/00021369.1991.10870699

6. G.O. Igile, W. Oleszek, M. Jurzysta, S. Burda, Journal of Agricultural and Food Chemistry, 22, 2445(1994), DOI: 10.1021/jf00047a015

7. A. Sinisi, E. Millan, S.M. Abay, A. Habluetzel. Journal of Natural Products, 78, 1618(2015), DOI:10.1021/acs.jnatprod.5b00179

8. G.O. Igile, W. Oleszek, M. Jurzysta, R. Aquino, Journal of Natural Products, 589, 1438(1995), DOI: $10.1021 / \mathrm{np} 50123 \mathrm{a} 016$

9. M. Jisaka, H. Ohigashi, T. Takagaki, H. Nozaki, Tetrahedron, 48, 625(1992), DOI:10.1016/S00404020(01)88123-0 
RASĀYAN J. Chem.

Vol. 13 | No. 4 |2577-2581| October - December | 2020

10. O. Quasie, Y.M. Zhang, H.J. Zhang, J. Luo, Phytochemistry Letters, 15, 16(2016), DOI:10.1016/j.phytol.2015.11.002

11. P. Erasto, D.S. Grierson, A.J. Afolayan, Food Chemistry, 45, 195(2007), DOI:10.1016/j.foodchem.2006.12.013

12. E.U. Eyong, I.J. Atangwho, E.D. Oku, M.A. Agiang, African Journal of Biotechnology, 10, 10258(2011)

13. A.A. Adedapo, A.T. Otesile, K.O. Soetan, Pharmaceutical Biology, 45, 564(2008), DOI:10.1080/13880200701498978

14. C.A. Egedigwe, C.E. Eijike, I.I. Ijeh, G.I. Onwuka, African Journal of Traditional, Complementary and Alternative Medicine, 13, 89(2016), DOI:10.1080/13880209.2016.1216135

15. I.J. Atangwho, E.E. Edet, D.E. Uti, A.U. Obi, M.Z. Asmawi, Saudi Journal of Biological Sciences, 19, 385(2012), DOI:10.1016/j.sjbs.2012.05.003

16. D. Satria, M. Furqan, S. Hadisahputra, Rosidah, International Journal of Pharmacy and Pharmaceutical Sciences, 7, 73(2015).

17. R. Anggraeni, S. Hadisahputra, J. Silalahi, D. Satria, International Journal of PharmTech Research, 6, 2032-2035 (2014).

18. P.A.Z. Hasibuan, C. Jessy, D. Satria. International Journal of Pharmacy and Pharmaceutical Sciences, 7, 155(2015).

19. U. Harahap, P.A.Z. Hasibuan, P. Sitorus, N. Arfian, D. Satria, Asian Pacific Journal of Cancer Prevention, 19(2), 565(2018), DOI:10.22034/APJCP.2018.19.2.565

20. Y. Tine, Y. Yang, F. Renucci, J. Costa, A. Wele, J. Paolini. Natural Product Communications, 12(12), 1865(2017), DOI: 10.1177/1934578X1701201213

21. Rosidah, P.A.Z. Hasibuan, G. Haro, P. Masri, D. Satria, Asian Journal of Pharmaceutical and Clinical Research, 11(1), 33(2018), DOI:10.22159/ajpcr2018.v11s1.26560

22. D. Satria, J. Silalahi, G. Haro, S. Ilyas, P.A.Z. Hasibuan, Asian Pacific Journal of Cancer Prevention, 18(2), 399(2017), DOI:10.22034/APJCP.2017.18.2.399

23. D. Satria, J. Silalahi, G. Haro, S. Ilyas, P.A.Z. Hasibuan, Rasayan Journal of Chemistry, 12(2), 803(2019), DOI: 10.31788/RJC.2019.1225180

24. M.F. Lubis, P.A.Z. Hasibuan, U. Harahap, Asian Journal of Pharmaceutical Research, 7(4), 12(2019), DOI:10.22270/ajprd.v7i4.533

25. N. Auliafendry, Rosidah, Yuandani, S. Suryani, D. Satria, Open Acccess Macedonian Journal of Medical Sciences, 7(1), 24(2019), DOI:10.3889/oamjs.2019.017

26. A. Dalimunthe, P.A.Z. Hasibuan, D. Satria, Open Acccess Macedonian Journal of Medical Sciences, 7(9), 1422(2019), DOI:10.3889/oamjs.2019.317

27. A. Dalimunthe, P.A.Z. Hasibuan, D. Satria, Asian Journal of Pharmaceutical and Clinical Research, 10(11), 404(2017), DOI:10.22159/ajpcr.2017.v1oi11.20204

28. A. Zurynn, L. Anna, S.M. Barbara, K.W. Anna, G. Maciej, International Journal of Oncology, 48, 2521(2016), DOI:10.3892/ijo.2016.3444

29. V.R. Yadav, P. Sahdeo, S. Bokyung, K. Ramaswamy, B.A. Bharat, Toxins, 2, 2428(2010)

30. C.E. Elson, S.G. Yu, The Journal of Nutrition, 124, 607(1994), DOI:10.3390/toxins2102428

31. G.J. Kellof. C.W. Boone, J.A. Crowell, V.E. Steele, R.A. Lubet, L.A. Doody, W.F. Malone, Journal of Cellular Biochemistry, 26, 1(1996), DOI:10.1002/jcb.240630703

32. H. Liao, X. Bao, J. Zhu, J. Qu, Y. Zhen, Chemico-Biological Interactions, 242, 91(2015), DOI:10.1016/j.cbi.2015.09.022

33. Y. Safdari, M. Khalil, M.A. Ebrahizmadeh, Y. Yazdani, S. Farajnia, Pharmacological Research, 93, 1(2015), DOI:10.1016/j.phrs.2014.12.004

34. N. Ferrara, H.P. Gerber, J. LeCounter, Nature Medicine, 9, 669(2003), DOI:10/1038/nm0603-669

[RJC-5625/2020] 